\title{
SIFAT FISIS DAN MEKANIS PURUN BAJANG SEBAGAI SUBSTITUSI PURUN DANAU DAN PURUN TIKUS
}

\author{
Physical and Mechanical Properties of Purun Bajang as Substitution of Purun \\ Danau and Purun Tikus \\ Dwi Harsono \\ Balai Riset dan Standardisasi Industri \\ Jl. P. Batur Barat No.2. Telp./Fax. 0511-4772461/0511-4772115 Banjarbaru \\ E-mail : baristand.banjarbaru@gmail.com \\ Diterima, 12 September 2013, disetujui 28 Nopember 2013
}

\begin{abstract}
ABSTRAK
Masalah yang dihadapi oleh pengrajin purun Kalimantan Selatan yaitu berkurangnya bahan baku purun yang sudah umum digunakan seperti purun danau dan purun tikus, sehingga menyebabkan timbulnya usaha untuk memanfaatkan purun bajang yang merupakan purun belum dikenal namun memiliki potensi cukup besar sebagai bahan baku kerajinan purun. Tujuan dari penelitian ini adalah untuk memperoleh informasi mengenai sifat fisis dan mekanis purun bajang serta purun tikus dan purun danau sebagai pembanding untuk sibstitusi purun tikus dan danau.

Dari hasil penelitian dapat disimpulkan bahwa performance purun bajang hampir sama dengan purun lain yang sudah dikomersilkan baik warna maupun kesan raba, namun purun bajang relatif lebih licin dibandingkan purun tikus dan danau. Purun bajang dapat dimanfaatkan sebagai bahan substitusi bahan purun tikus dan danau yang sudah dikomersilkan, namun perlu diperhatikan mengenai kekuatan tariknya karena memiliki nilai kuat tarik yang sangat rendah. Purun bajang dapat digunakan sebagai bahan anyaman setelah proses pengeringan tanpa dilakukan penumbukan karena dapat menyebabkan semakin rapuh kuat tariknya.
\end{abstract}

Kata kunci : purun, sifat fisis, sifat mekanis

\section{ABSTRACT}

The problem faced by purun craftsmen is the reduced of purun raw material which commonly used such as purun danau and purun tikus. Hence it tends to utilized purun bajang which lesser known but potential used as a raw material purun craft. The research aims to obtain the information on the physical and mechanical properties of purun bajang compared with purun tikus and purun danau as substituted of purun tikus and purun danau.

The research conclude that purun bajang's performance is almost same as another commercial purun in terms colour and impression touch, but purun bajang relative slippery than purun tikus and purun danu. Purun bajang can be used as material substitution of commercialized purun tikus and purun danau, but it is noteworthy because of the tensile strength which it have very low tensile strength. Purun bajang can be used as woven material after drying process without any pulverization because it cause increasingly fragile tensile strength.

Keywords: purun, physical properties, mechanical properties

\section{PENDAHULUAN}

Kalimantan Selatan memiliki beberapa subsektor kerajinan, salah satu

dengan baik, dapat menjadikan purun diantaranya kerajinan purun. Jika dikelola sebagai pendongkrak pembangunan ekonomi daerah. Propinsi Kalimantan 
Selatan memiliki bahan baku tumbuhan purun yang cukup potensial, mengingat sebagian besar wilayah Kalimantan Selatan terdiri dari rawa-rawa yang selalu tergenang air sepanjang tahun dan memiliki struktur tanah gambut yang sifatnya adalah asam $(\mathrm{PH}<7)$ yang merupakan tempat tumbuh tanaman purun (Wianto, 2011). Data Dinas Perindustrian Perdagangan dan Penanaman Modal Barito Kuala pada tahun 2006 persebaran jenis tumbuhan purun mencapai \pm 713 hektar, meliputi purun danau \pm 641 hektar dan purun tikus \pm 72 hektar (Kosjoko, et al., 2011). Fatriani (2010) mengemukakan produk kerajinan anyaman purun di Kalimantan Selatan meliputi topi, tikar, bakul serta tempat tissue dan tas. Dari produk tersebut memerlukan proses yang sama yaitu setelah dipanen, purun dikeringkan kemudian dipipihkan, selanjutnya dianyam dengan teknik yang berbeda sesuai produk yang diinginkan.

Produk kerajinan menjadi salah satu komoditas ekspor Kalimantan Selatan yang potensial dikembangkan, karena produk ini cukup diminati di pasar dunia sehingga permintaannya cukup besar. Namun produk kerajinan hingga kini masih belum mampu memenuhi permintaan pasar, akibat terkendala dengan masalah desain, kualitas produk dan lainnya, termasuk kesulitan memenuhi permintaan dalam jumlah besar atau terkait dengan bahan baku. Masalah yang dihadapi oleh pengrajin purun Kalimantan Selatan yaitu berkurangnya bahan baku purun yang sudah umun digunakan pengrajin seperti purun danau dan purun tikus, sehingga menyebabkan timbulnya usaha untuk memanfaatkan purun yang belum dikenal namun memiliki potensi cukup besar sebagai bahan baku kerajinan purun. Salah satunya adalah purun bajang.

Tujuan dari penelitian ini adalah untuk memperoleh informasi sifat fisis dan mekanis purun bajang serta purun tikus dan purun danau sebagai pembanding sehingga diharapkan purun bajang dapat sebagai substitusi purun tikus dan danau.

\section{BAHAN DAN METODE}

Jenis purun yang diteliti adalah purun bajang serta purun tikus dan purun danau. Purun tersebut merupakan purun yang sudah tua diambil/dipanen dari tempat tumbuhnya. Purun yang sudah tua dapat dilihat pada saat dicabut, apabila akar purun terikut bila dicabut maka purun tersebut dapat dikatakan tua, sedangkan bila pelepah bawahnya terlihat berwarna putih dan meninggalkan akar bila dicabut maka purun tersebut masih muda. Kemudian purun yang telah dipanen dijemur di tempat terbuka sampai kering. Biasanya purun akan berubah warna menjadi kekuningan.

Peralatan yang digunakan antara lain timbangan, bak perendaman, kalifer, alat uji kekuatan tarik.

Sifat fisis yag diuji dalam penelitian ini adalah kadar air purun segar, kadar air purun setelah dijemur dan kerapatan. Untuk keperluan tersebut, dari setiap contoh uji dibedakan antara batang bagian pangkal dan batang bagian ujung dengan ukuran panjang $5 \mathrm{~cm}$ dan diameter mengikuti tebal purun. Semua contoh uji setelah ditimbang berat awal pada suhu kamar $\left( \pm 25^{\circ} \mathrm{C}\right)$ serta diukur dimensinya untuk mendapatkan nilai kerapatan, kemudian dikeringkan dalam oven pada suhu $103^{\circ} \mathrm{C}$ sampai beratnya konstan. Selanjutnya semua contoh uji ditimbang untuk mendapatkan berat akhir. Untuk mendapatkan nilai volume purun $\left(\mathrm{cm}^{3}\right)$, purun dianggap silinder kemudian diukur dengan kondisi kering udara, dimana rumus volume silinder adalah $(\pi / 4) d^{2} . t$; dimana $d$ =diameter; $t$ =tebal. Kadar air dihitung berdasarkan rumus :

$$
\text { Kadar air }(\%)=\frac{B a-B k t}{B k t} \times 100 \%
$$

Keterangan $: \mathrm{Ba}=$ Berat awal $(\mathrm{g})$;

$$
\text { Bkt }=\text { Berat kering tanur }(\mathrm{g})
$$

Sedangkan kerapatan purun merupakan perbandingan berat dan volume dalam keadaan kadar air kering udara, rumusnya sebagai berikut : 


$$
\text { Kerapatan }\left(\mathrm{g} / \mathrm{cm}^{3}\right)=\frac{B k t}{V k u}
$$

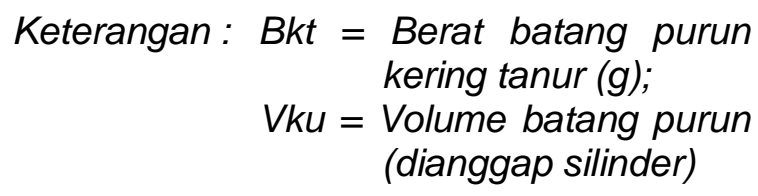

Sifat mekanis pada penelitian ini adalah kekuatan tarik. Masing-masing ujung sampel sepanjang $10 \mathrm{~cm}$ dijepit pada rahang penarik pada mesin uji tarik, sehingga panjang kedua ujung jepitan berjarak $10 \mathrm{~cm}$. Kemudian gaya tarik dikenakan pada kedua ujung jepitan tali kertas hingga putus. Gaya tarik hingga putus terukur pada penunjuk ukuran gaya tarik maksimum. Adapun perhitungan luas batang purun menggunakan rumus luas persegi, karena diasumsikan anyaman purun berbentuk pipih. Pengujian kekuatan tarik menggunakan rumus :

$$
\sigma=\frac{F}{A}
$$

Keterangan : $\sigma=$ kekuatan tarik maksimum dalam satuan $\left(\mathrm{kg} / \mathrm{cm}^{2}\right)$; $F=$ gaya tarik maksimum sampai batang purun putus (kg); $A$ = luas penampang batang purun (dianggap persegi karena berbentuk pipih) $\left(\mathrm{cm}^{2}\right)$

Data pengujian kadar air dan kerapatan yang diperoleh dari hasil penelitian dianalisa secara statistik dengan menggunakan rancangan acak lengkap (RAL) faktorial yang diamati yaitu variasi letak batang purun, (pangkal dan ujung) serta variasi kondisi purun, (basah dan kering). Sedangkan data pengujian kuat tarik pada purun bajang pada penelitian akan dianalisa pada bagian tengah saja karena pada proses penganyaman menggunakan lembaran purun secara keseluruhan (pangkal sampai ujung) dengan pola berselang seling satu sama lain.

\section{HASIL DAN PEMBAHASAN}

\subsection{Kadar Air}

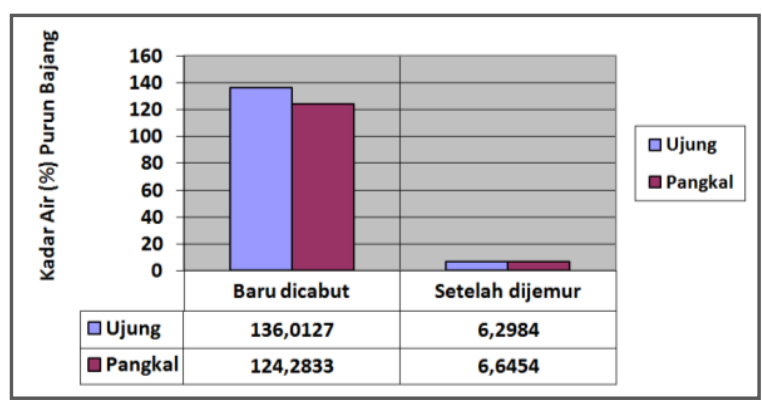

Gambar 1. Rata-rata hasil uji kadar air purun bajang berdasarkan letak batang dan kondisi purun.

Berdasarkan hasil pengujian terlihat bahwa kadar air dari purun bajang memiliki nilai yang sangat berbeda antara baru dicabut atau baru dipanen dengan purun setelah dilakukan proses penjemuran. Dan juga terdapat perbedaan antara bagian pangkal dan bagian ujung. Nilai rata-rata kadar air bagian pangkal purun bajang yang baru dicabut yaitu $124,2833 \%$ dan setelah dijemur $6,6454 \%$, sedangkan nilai rata-rata kadar air bagian ujung purun bajang yang baru dicabut yaitu 136,0127\% dan setelah dijemur 6,2984\% (Gambar 1)

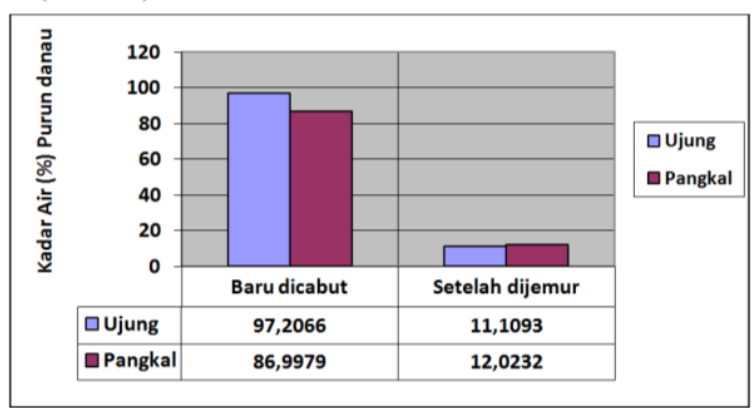

Gambar 2. Rata-rata hasil uji kadar air purun danau berdasarkan letak batang dan kondisi purun.

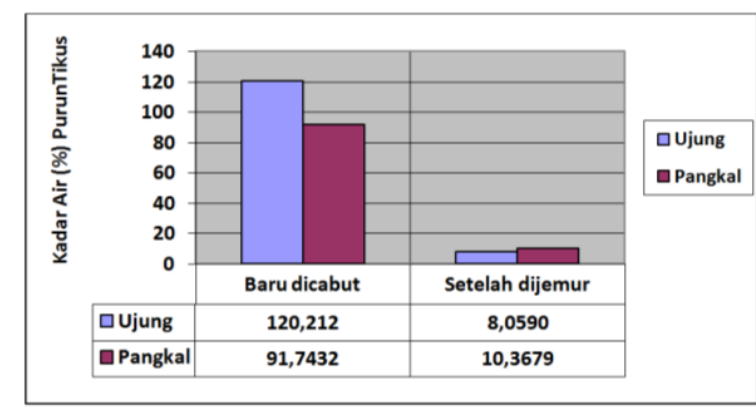

Gambar 3. Rata-rata hasil uji kadar air purun tikus berdasarkan letak batang dan kondisi purun. 
Seperti halnya pada purun bajang, nilai kadar air kedua jenis purun danau dan purun tikus memiliki nilai yang sangat berbeda antara baru dicabut atau baru dipanen dengan purun setelah dilakukan proses penjemuran. Dan juga terdapat perbedaan antara bagian pangkal dan bagian ujung. Nilai rata-rata kadar air bagian pangkal purun danau yang baru dicabut yaitu $86,9979 \%$ dan setelah dijemur $12,0232 \%$, sedangkan nilai ratarata kadar air bagian ujung purun danau yang baru dicabut yaitu $97,2066 \%$ dan setelah dijemur 11,1093\% (Gambar 2). Sedangkan nilai rata-rata kadar air bagian pangkal purun tikus yang baru dicabut yaitu $91,7432 \%$ dan setelah dijemur 10,3679\%, sedangkan nilai rata-rata kadar air bagian ujung purun tikus yang baru dicabut yaitu $120,2120 \%$ dan setelah dijemur 8,0590\% (Gambar 3).

Berdasarkan hasil pembandingan pengujian terlihat bahwa kadar air dari purun bajang memiliki nilai kadar air yang paling tinggi pada kondisi baru dicabut/dipanen dibandingkan dengan purun danau dan purun tikus, baik pada pangkal maupun pada ujung batang purun. Namun memiliki nilai kadar air yang paling rendah pada kondisi setelah dijemur/ dikeringkan. Hal tersebut dimungkinkan purun bajang memiliki jaringan sel yang besar dan memiliki dinding sel yang tipis sehingga proses keluar masuknya air sangat mudah. Adapun nilai kadar air yang paling rendah pada kondisi baru dipanen pada pangkal maupun ujung batang adalah purun danau. Serta memiliki nilai kadar air yang paling tinggi pada kondisi setelah dijemur / dikeringkan. $\mathrm{Hal}$ tersebut kemungkinan purun danau memiliki jaringan sel yang rapat dan memiliki dinding sel yang tebal sehingga proses keluar masuknya air lebih sulit. Disamping itu, berdasarkan pengamatan visual pada purun danau lebih kasar dibandingkan purun bajang dan purun tikus yang relatif licin. Hal tersebut berarti purun danau mempunyai kandungan silika yang lebih banyak. Namun purun tidak seperti bambu andong segar yang memiliki nilai kadar air cenderung lebih tinggi pada bagian pangkal dibandingkan dengan bagian tengah, hal tersebut karena bagian pangkal bambu dekat dengan tanah dan akar yang berfungsi menyerap air dan hara dari tanah sedangkan bagian tengah bambu lebih banyak mengalami evapotranspirasi (Saefudin, dkk, 2008). Perbedaan kadar air pada purun tersebut kemungkinan purun memiliki struktur anatomi yang berbeda dengan bambu.

\subsection{Kerapatan}

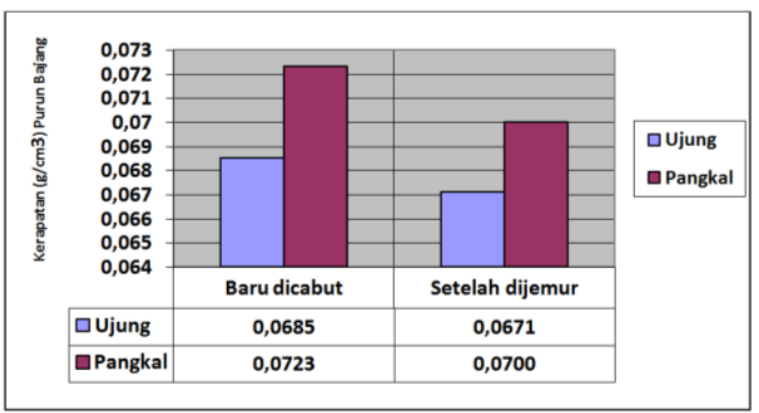

Gambar 4. Rata-rata hasil uji kerapatan purun bajang berdasarkan letak batang dan kondisi purun.

Berdasarkan hasil pengujian terlihat bahwa kerapatan dari purun bajang memiliki nilai yang sangat berbeda antara baru dicabut atau baru dipanen dengan purun setelah dilakukan proses penjemuran. Dan juga terdapat perbedaan antara bagian pangkal dan bagian ujung. Nilai rata-rata kerapatan bagian pangkal purun bajang yang baru dicabut yaitu $0,0723 \mathrm{~g} / \mathrm{cm}^{3}$ dan setelah dijemur 0,0700 $\mathrm{g} / \mathrm{cm}^{3}$, sedangkan nilai rata-rata kerapatan bagian ujung purun bajang yang baru dicabut yaitu $0,0685 \mathrm{~g} / \mathrm{cm}^{3}$ dan setelah dijemur 0,0671 g/cm ${ }^{3}$ (Gambar 4).

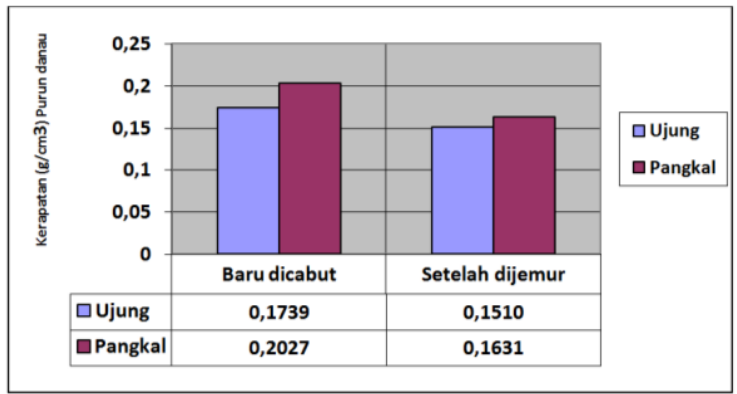

Gambar 5. Rata-rata hasil uji kerapatan purun danau berdasarkan letak batang dan kondisi purun. 


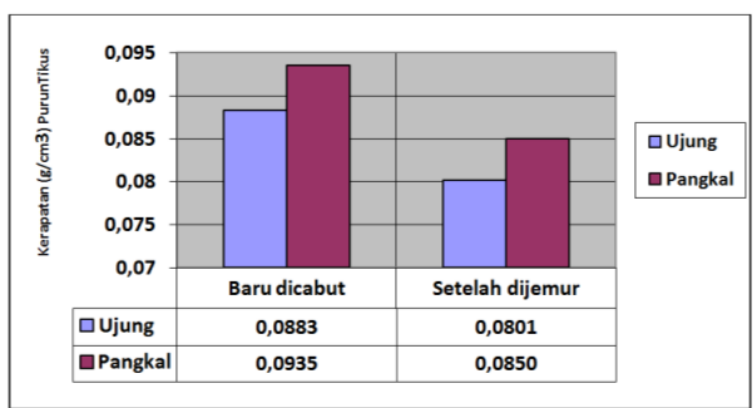

Gambar 6. Rata-rata hasil uji kerapatan purun tikus berdasarkan letak batang dan kondisi purun.

Seperti halnya pada purun bajang, nilai kerapatan kedua jenis purun danau dan purun tikus memiliki nilai yang sangat berbeda antara baru dicabut atau baru dipanen dengan purun setelah dilakukan proses penjemuran. Pula terdapat perbedaan antara bagian pangkal dan bagian ujung. Nilai rata-rata kerapatan bagian pangkal purun danau yang baru dicabut yaitu $0,2027 \mathrm{~g} / \mathrm{cm}^{3}$ dan setelah dijemur $0,1631 \mathrm{~g} / \mathrm{cm}^{3}$, sedangkan nilai ratarata kerapatan bagian ujung purun danau yang baru dicabut yaitu $0,1739 \mathrm{~g} / \mathrm{cm}^{3}$ dan setelah dijemur $0,1510 \mathrm{~g} / \mathrm{cm}^{3}$ (Gambar 5). Sedangkan nilai rata-rata kerapatan bagian pangkal purun tikus yang baru dicabut yaitu $0,0935 \mathrm{~g} / \mathrm{cm}^{3}$ dan setelah dijemur 0,0850 $\mathrm{g} / \mathrm{cm}^{3}$, sedangkan nilai rata-rata kerapatan bagian ujung purun tikus yang baru dicabut yaitu $0,0883 \mathrm{~g} / \mathrm{cm}^{3}$ dan setelah dijemur $0,0801 \mathrm{~g} / \mathrm{cm}^{3}$ (Gambar 6).

Berdasarkan hasil pembandingan pengujian terlihat bahwa kerapatan dari purun bajang memiliki nilai kerapatan yang paling rendah baik pada pangkal maupun pada ujung batang purun serta pada kondisi baru dicabut/dipanen ataupun setelah dipanen bila dibandingkan dengan purun danau dan purun tikus. Hal tersebut dimungkinkan purun bajang memiliki jaringan sel yang besar dan memiliki dinding sel yang tipis sehingga penyusun ikatan antar sel sangat rendah. Adapun nilai kerapatan yang paling tinggi pada kondisi baru dipanen pada pangkal maupun ujung batang adalah purun danau. Serta memiliki nilai kerapatan yang paling tinggi pada kondisi setelah dijemur/ dikeringkan. Hal tersebut dimungkinkan purun danau memiliki jaringan sel yang rapat dan memiliki dinding sel yang tebal sehingga ikatan antar penyusun sel semakin kuat. Kerapatan merupakan perbandingan antara massa purun dengan volumenya dalam kondisi kering udara. Kerapatan sangat berhubungan dengan kekuatan tarik purun. Semakin tinggi kerapatan maka semakin tinggi kekuatan tarik, dan pada umunnya akan memiliki dinding sel yang banyak dan tebal.

\subsection{Kuat Tarik}

Kekuatan tarik merupakan ukuran kemampuan purun dalam menahan tarikan baik pada proses anyaman maupun setelah menjadi produk anyaman tanpa terjadinya perubahan permanen atau dapat kembali ke bentuk semula.

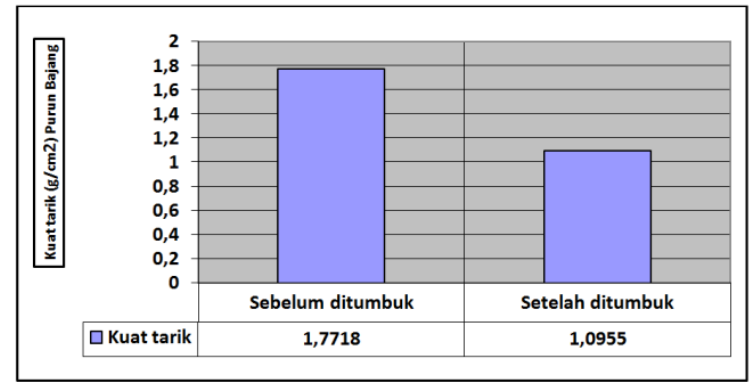

Gambar 7. Rata-rata hasil uji kuat tarik purun bajang berdasarkan perlakuan sebelum ditumbuk dan setelah ditumbuk.

Berdasarkan hasil pengujian terlihat bahwa kekuatan tarik dari purun bajang memiliki nilai yang sangat berbeda antara sebelum ditumbuk/dipipihkan atau setelah ditumbuk/dipipinkan. Nilai rata-rata kekuatan tarik purun bajang sebelum ditumbuk yaitu $1,7718 \mathrm{~g} / \mathrm{cm}^{3}$ dan setelah ditumbuk 1,0955 g/cm (Gambar 7).

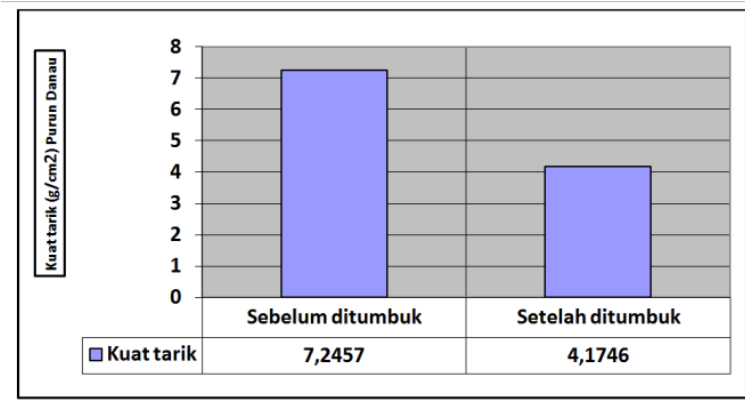

Gambar 8. Rata-rata hasil uji kuat tarik purun danau berdasarkan perlakuan sebelum ditumbuk dan setelah ditumbuk. 


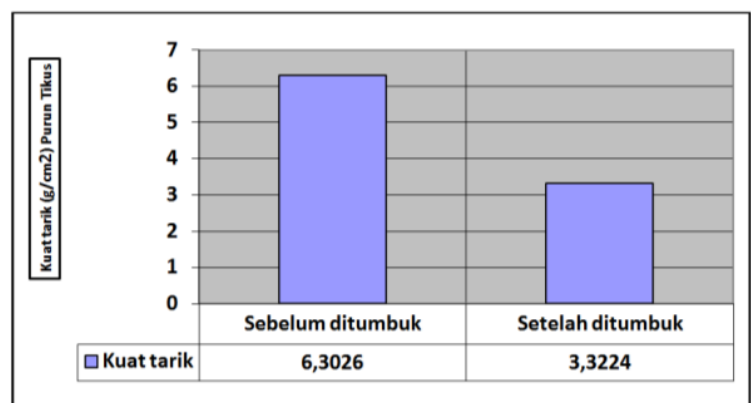

Gambar 9. Rata-rata hasil uji kuat tarik purun tikus berdasarkan perlakuan sebelum ditumbuk dan setelah ditumbuk.

Berdasarkan hasil pengujian terlihat bahwa kekuatan tarik dari purun bajang memiliki nilai yang sangat berbeda Nilai rata-rata kekuatan tarik purun bajang sebelum ditumbuk yaitu $1,7718 \mathrm{~g} / \mathrm{cm}^{3}$ dan setelah ditumbuk $1,0955 \mathrm{~g} / \mathrm{cm}^{3}$. Seperti halnya pada purun bajang, nilai kekuatan tarik kedua jenis purun yaitu purun danau dan purun tikus memiliki nilai yang sangat berbeda antara antara sebelum ditumbuk atau setelah ditumbuk. Nilai rata-rata kekuatan tarik purun danau sebelum ditumbuk 7,2457 $\mathrm{g} / \mathrm{cm}^{3}$ dan setelah ditumbuk 4,1746 $\mathrm{g} / \mathrm{cm}^{3}$ (Gambar 8), sedangkan nilai rata-rata kekuatan tarik purun tikus sebelum ditumbuk 6,3026 $\mathrm{g} / \mathrm{cm}^{3}$ dan setelah ditumbuk $3,3224 \mathrm{~g} / \mathrm{cm}^{3}$ (Gambar 9).

Berdasarkan hasil pembandingan pengujian terlihat bahwa kerapatan dari purun bajang memiliki nilai kekuatan tarik yang paling rendah baik pada perlakuan sebelum ditumbuk maupun setelah ditumbuk. Sedangkan yang memiliki nilai yang tinggi pada kekuatan tarik adalah purun danau. Hal tersebut berhubungan dengan kerapatan. Kerapatan merupakan perbandingan antara massa purun dengan volumenya dalam kondisi kering udara. Kerapatan sangat berhubungan dengan kekuatan tarik purun. Semakin tinggi kerapatan maka semakin tinggi kekuatan tarik, dan pada umunnya akan memiliki dinding sel yang banyak dan tebal. Seperti halnya pandan, purun dalam keadaan basah memiliki kekuatan tarik yang rendah dibandingkan purun yang sudah kering. Kekuatan tarik merupakan salah satu sifat serat yang sangat penting terhadap tarikan-tarikan pada saat pengolahan selanjutnya (Gusmailina, 2010).

\section{KESIMPULAN}

Konstruksi mesin cukup sederhana, Purun bajang secara performance (warna dan kesan raba) dapat sebagai bahan substitusi bahan purun tikus dan danau yang sudah dikomersilkan, namun nilai kekuatan tariknya di bawah purun tikus dan danau. Purun bajang dapat digunakan sebagai bahan anyaman setelah proses pengeringan tanpa dilakukan penumbukkan.

\section{DAFTAR PUSTAKA}

1. Fatriani. 2010. Produktivitas dan Rendemen Anyaman Purun Danau (Lepironia mucronata rich) di Desa Harusan, Kabupaten Hulu Sungai Utara, Kalimantan Selatan. Jurnal Hutan Tropis. 11 (30) : 56-64. Edisi September 2010

2. Gusmailina. 2010. Peningkatan Teknik Pengolahan Pandan (Bagian I): Pewarnaan dan Pengeringan. Jurnal Penelitian Hasil Hutan. 28 (1) : 66-76. Pusat Penelitian dan Pengembangan Hasil Hutan. Bogor.

3. Kosjoko, A,. A.A. Sonief, dan D. Sitikno. 2011. Pengaruh Waktu Perlakuan Kalium Permanganate $\left(\mathrm{KmnO}_{4}\right)$ Terhadap Sifat Mekanik Komposit Serat Purun Tikus (Eleocharis dulcis). Jurnal Rekayasa Mesin. 2 (3) : 193-198.

4. Saefudin,. E. Basri,. Dan N. Hadjib. 2008. Pengaruh Umur, Posisi Batang dan Tingkat Kekeringan Terhadap Sifat Fisik dan Kualitas Pengeringan Bambu Andong. Jurnal Penelitian Hasil Hutan. 26 (4) : 289-298. Pusat Penelitian dan Pengembangan Hasil Hutan. Bogor.

5. Wianto, T,. Ishaq,. A. Faisal,. dan A, Hamdi. 2011. Rekayasa Tumbuhan Purun Tikus (Eleocharis Dulcis) sebagai Substitusi Bahan Matrik Komposit Pada Pembuatan Papan Partikel. Jurnal Fisika FLUX.8 (2) :154-164. 
Sifat Fisis dan Mekanis Purun Bajang sebagai Substitusi Purun Danau dan Purun Tikus.....Dwi Harsono 